\title{
Residual soil nitrate as affected by giant reed cultivation and cattle slurry fertilisation
}

\author{
Enrico Ceotto, ${ }^{1}$ Rosa Marchetti, ${ }^{2}$ Fabio Castelli ${ }^{3}$ \\ ${ }^{1}$ CREA - Council for Agricultural Research and Economics, Research Center for Agriculture and \\ Environment, Bologna; ${ }^{2}$ CREA - Council for Agricultural Research and Economics, Research Center for \\ Animal Production and Acquaculture, San Cesario sul Panaro (MO); ${ }^{3}$ CREA - Council for Agricultural \\ Research and Economics, Research Center for Viticulture and Enology, Conegliano (TV), Italy
}

\begin{abstract}
The residual soil nitrate (RSN) is the amount of nitrate which remains in soil profile after crop uptake has ceased, typically in the autumn. The RSN is prone to leaching and therefore poses serious environmental concerns, especially in areas with intensive livestock activities. Little is known about the ability of the energy grass giant reed in leaving low RSN. Such ability would add a desirable environmental benefit to giant reed cultivation. This article reports on snapshot measurements of RSN across soil profile in the autumn of three consecutive years: 2010, 2011 and 2012. Soil nitrate content was measured on soil samples collected from the soil layers $0-0.2 \mathrm{~m}, 0.2-0.4 \mathrm{~m}, 0.4-0.6 \mathrm{~m}$ and $0.6-0.8 \mathrm{~m}$. The $\mathrm{RSN}$ of giant reed was compared with RSN of the energy crops sweet sorghum and poplar short rotation coppice (SRC). The three energy crops were treated with two fertilisation regimes: $0 \mathrm{~kg} \mathrm{~N}$ $\mathrm{ha}^{-1}$ (Control) and $20 \mathrm{~mm}$ of cattle slurry (CS20). Soil samples were also taken for a reference crop of winter wheat following winter wheat and receiving no $\mathrm{N}$ supply. Our findings for the three years of experiment can be summarised as follows: i) in case of
\end{abstract}

Correspondence: Enrico Ceotto, CREA - Council for Agricultural Research and Economics, Research Center for Agriculture and Environment, via di Corticella 133, 40128 Bologna, Italy.

Tel.: +39.051.6316833 - Fax: +39.051.374857.

E-mail: enrico.ceotto@crea.gov.it; enricoceotto@gmail.com

Key words: Animal waste disposal; dedicated energy crops; soil ecosystems services; unfertilised crops.

Funding: this study was financed by the projects BIOSEA and SUSCACE of the Italian Ministry of Agricultural Food and Forestry Policies (MiPAAF).

Conflict of interests: the authors have no conflict of interest to declare.

Received for publication: 26 March 2018.

Accepted for publication: 4 September 2018.

(C) Copyright E. Ceotto et al., 2018

Licensee PAGEPress, Italy

Italian Journal of Agronomy 2018; 13:1264

doi:10.4081/ija.2018.1264

This article is distributed under the terms of the Creative Commons Attribution Noncommercial License (by-nc 4.0) which permits any noncommercial use, distribution, and reproduction in any medium, provided the original author(s) and source are credited. the unfertilised Control, the three dedicated energy crops giant reed, sweet sorghum and poplar SRC left in soil profile in the autumn significantly lower amounts of RSN compared to the reference crop of wheat. Hence, all the three energy crops provided in similar manner the environmental benefit of leaving lower RSN; ii) in case of cattle slurry application the real advantage of giant reed cultivation became surprisingly evident. In fact, in three subsequent years the treatment giant reed CS20 never determined RSN significantly higher than RSN for giant reed Control. The RSN for giant reed with treatment CS20 was significantly lower than that the reference crop of wheat in all the three years. Unlike poplar SRC and sweet sorghum, giant reed exerted effective soil nitrate removal with a relatively high rate of cattle slurry application. Hence, this species can be regarded as suitable not only to utilise livestock effluents, but also to reduce the risk of nitrate pollution in many land use situations dealing with nitrogen surplus.

\section{Introduction}

The energy grass giant reed (Arundo donax L.) can provide several concurrent ecosystem services. In fact, beside to its outstanding biomass productivity (Webster et al., 2016) this species promotes substantial soil carbon sequestration (Nocentini and Monti, 2017), high nitrogen (N) use efficiency (Ceotto et al., 2015), wastewater treatment and phytoremediation of heavymetal contaminated soils (Barbosa et al., 2015). While giant reed has been intensively studied over the last decade, little attention has been given to how its cultivation can affect residual soil nitrate content (RSN).

In areas with intensive livestock activities the animal waste disposal poses serious environmental concern due to pollution of both water and atmosphere. In aerated soils, most of the nitrogen applied as manure is converted to nitrate in the soil. Nitrate, a water-soluble anion, moves readily with percolating water. In anoxic conditions, nitrate can be denitrified and lost to the atmosphere (Keeney and Hatfield, 2001).

Owing to the widespread concern about groundwater pollution determined by the agricultural land use, the assessment of the risk of nitrate leaching is a key feature in cropping system evaluation. The key problem of water pollution is the so-called untimely nitrate, i.e. the nitrate which remains in soil profile after crop uptake has ceased and therefore is vulnerable to loss in drainage (Stockdale et al., 1997). Whether or not untimely nitrate becomes nitrate pollution depends on precipitation and physical properties of the soil (Addiscott, 2005). We here refer to RSN because this notation has been in use for a long time (Olson et al., 1976) and has been predominantly adopted in agronomic literature (Bausch 
and Delgado, 2005; Liu et al., 2017). A crop that minimises the amount of RSN performs a desired environmental service. In fact, minimising $\mathrm{N}$ losses from cropping systems is mandatory in compliance with the Nitrate Directive 91/676/EEC that addresses the disposal of livestock effluents and the excessive use of mineral $\mathrm{N}$ fertilisers (Council Directive 91/676/EEC).

In the Po Valley, Northern Italy, livestock manure is predominantly applied to maize, and there is the need to identify alternative crops, suitable to receive slurry applications, especially for nonirrigated conditions. An effective way to minimise nitrate leaching to ground water consists on assuring vigorous crop growth and high $\mathrm{N}$ assimilation capacity throughout the growing season (Follett, 2001). Perennial crops allow nitrogen and water removal far beyond the capability of most annual crops (Ceotto and Spallacci, 2006). Owing to its extended canopy cover (Cosentino et al., 2016), deep rooting systems (Barco et al., 2018), and high $\mathrm{N}$ uptake (Ceotto et al., 2015) giant reed in principle could be regarded as well suited to remove soil nitrate, leaving low RSN, although no data were reported to substantiate this hypothesis.

The scope of this study was to assess the ability of the energy crop giant reed with and without cattle manure fertilisation to leave low amounts of nitrate in soil at the start of the leaching-prone winter season. A crop of continuous winter wheat (Triticum aestivum L.), and the widespread energy crops sweet sorghum (Sorghum bicolor L. Moench), and poplar short rotation coppice (SRC; Poplar x Canadensis, Moench) served as terms of comparison.

\section{Materials and methods}

\section{Site characterisation and agronomic details}

In the years from 2010 to 2012 a field experiment on cattle slurry applications to giant reed was conducted at the experimental station of CREA, located in Anzola dell'Emilia (Bologna), Low Po

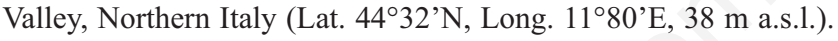
Other two independent field experiments with the same fertilisation treatments were conducted in the same years with the herbaceous annual sweet sorghum and the woody perennial poplar.

The soil of the site is a silty-loam, classified as Udifluventic Haplustepts fine silty, mixed mesic (Soil Survey Staff, 2003). The climate is temperate sub-continental, due to the relatively long distance from the sea (about $200 \mathrm{~km}$ ). Average annual air temperature for the location is $12.9^{\circ} \mathrm{C}$, and mean annual total rainfall is 755 $\mathrm{mm}$. The location is characterised by a relatively shallow water table, fluctuating between $1.1 \mathrm{~m}$ depth in winter and about $2 \mathrm{~m}$ depth in summer.

Details of the methodology of the three experiments were presented by Ceotto et al. (2014, 2015, 2016), who reported key findings of dry matter yield and nitrogen use efficiency (NUE) of the three dedicated energy crops. For this study, addressed on soil residual nitrate, we limited ourselves to the extreme fertilisation treatments applied to the three species in the years 2010, 2011 and 2012: i) unfertilised control with no N supply (Control); ii) $20 \mathrm{~mm}$ of cattle slurry (CS20). Owing to the variability of slurry composition, the amount of $\mathrm{N}$ applied with treatment CS20 was $400 \mathrm{~kg} \mathrm{~N}$ $\mathrm{ha}^{-1}$ in 2010, $360 \mathrm{~kg} \mathrm{~N} \mathrm{ha}^{-1}$ in 2011, and $360 \mathrm{~kg} \mathrm{~N} \mathrm{ha}^{-1}$ in 2012.

These fertilisation treatments were applied each year on the same plots for both giant reed and poplar SRC. For sweet sorghum, the treatments where annually applied to different fields of the same farm, and the preceding crop was always winter wheat, for five subsequent years, from 2008 to 2012 . Cattle slurry was dis- tributed on soil surface. Soil incorporation of slurry, not compulsory in the area, could be problematic for perennial crops due to the presence of stumps (poplar), rhizomes (giant reed) and rooting systems. The experimental design was a randomised block with three replications, conducted in separate fields for each crop. No irrigation was applied.

A previous study, conducted in a location of the same region, indicated that the amount of RSN accumulated in the profile of a silty-clay soil at the end of autumn was particularly high in case of a winter wheat crop harvested in July, with the soil ploughed during the summer and no crop $\mathrm{N}$ uptake in the period extending from July to November (Ceotto, 1999). Therefore, we also collected soil samples in reference fields of the same farms where winter wheat had been harvested in the summer preceding soil sampling, and the fields had been re-sowed with winter wheat receiving no N supply during the autumn. The wheat crop following wheat, which represents a common situation in the area, was taken as reference for comparing the performances of the three dedicated energy crops.

\section{Soil sampling and analysis}

The soil of the individual plots was sampled in three dates: 30 November 2010, 6 December 2011 and 5 December 2012, which represent three snapshots of the soil status at the end of the autumn season. The sampled soil layers were $0 .-0.2 \mathrm{~m}, 0.2-0.4 \mathrm{~m}, 0.4-0.6$ $\mathrm{m}$, and $0.6-0.8 \mathrm{~m}$. In the first year (2010) only the replications I and II were sampled for the experiments of giant reed and poplar SRC and for the field of wheat, while the experiment on sweet sorghum was not sampled. In the two subsequent years all the replication plots I, II and III were sampled for the three experiments on giant reed, poplar SRC and sweet sorghum, and for the field of wheat. Unlike giant reed and poplar, soil samples for sorghum and wheat were collected in different fields of the same experimental farm over the years (Tables 1 and 2). For each plot and soil layer, five independent soil cores were collected at a distance of about $0.5 \mathrm{~m}$. Soil cores were collected using a $70 \mathrm{~mm}$ diameter soil sampler drill, model Eijkelkamp. The five cores of each plot were combined in one sample. A certain amount of sample was left to dry at ambient temperature, and then sieved; the remaining was frozen.

The sieved soil was used to determine the organic $\mathrm{C}$ through wet oxidation with dichromate, according to the Walkley-Black method, and total $\mathrm{N}$ using the Kjeldahl method according to Page et al. (1982). Soil nitrate $\mathrm{N}\left(\mathrm{NO}_{3}-\mathrm{N}\right)$ was extracted from the frozen soil samples, after thawing them at room temperature, by using 2 $\mathrm{mol} \mathrm{L}{ }^{-1} \mathrm{KCl}$ (soil/solution ratio 1:5) and measured colorimetrically with sulphanilamide after reduction to nitrite through a cadmium column, using an automatic analyser (AutoAnalyzer 3; Bran + Luebbe GmbH, Norderstedt, Germany), according to Keeney and Nelson (1982).

\section{Residual soil nitrate content}

We here considered the amount of RSN present in the soil profile at the end of autumn. Under our environmental conditions in this period crop water and $\mathrm{N}$ uptake have ceased and precipitation can overtake soil water retention leading to undesired nitrate leaching. Following Liu et al. (2017) RSN (in $\mathrm{kg} \mathrm{NO}_{3}-\mathrm{N} \mathrm{ha}^{-1}$ ) in each soil layer was calculated as follows:

$\mathrm{RSN}=\mathrm{Ti} \times \mathrm{Di} \times \mathrm{Ci} \times 0.01$

where $\mathrm{Ti}$ is the soil layer thickness $(0.2 \mathrm{~m})$;

Di is the soil bulk density $\left(\mathrm{kg} \mathrm{m}^{-3}\right)$;

$\mathrm{Ci}$ is the soil $\mathrm{NO}_{3}-\mathrm{N}$ concentration $\left(\mathrm{mg} \mathrm{NO} \mathrm{NO}_{3}-\mathrm{N} \mathrm{kg}^{-1}\right)$ of the corresponding layer; 
and 0.01 is the conversion coefficient accounting for $10,000 \mathrm{~m}^{2}$ $\mathrm{ha}^{-1} / 1,000,000 \mathrm{mg} \mathrm{kg}^{-1}$.

In this study the RSN was calculated for the soil layers $0-0.2 \mathrm{~m}$, 0.2-0.4 m, 0.4-0.6 m, and 06-0.8 m.

The values of soil bulk density were: $1.66 \mathrm{Mg} \mathrm{m}^{-3}( \pm 0.048)$ for soil layers from 0 to $0.6 \mathrm{~m}$ depth, and $1.53 \mathrm{Mg} \mathrm{m}^{-3}( \pm 0.048)$ for the soil layer from 0.6 to $0.8 \mathrm{~m}$. These values were determined with the core method, according to Blake and Hartge (1986) by collecting undisturbed soil samples using cylinders of $98 \mathrm{~cm}^{3}$ pressed horizontally into the soil. Soil samples were collected across the soil profile in three different observation points at the edge of poplar and giant reed plots.

\section{Statistical analysis}

The soil of the experimental plots of the giant reed and poplar SRC experiments was sampled in the years 2010, 2011 and 2012. The normal distribution of data was preliminarily assessed by the Shapiro-Wilk test. As data distribution was normal, it was not necessary to apply any data transformation. The statistical analysis was performed with the PROC MIXED of SAS (Littell et al., 1996), using the statement REML to deal with normal distribution (SAS Institute, 2009). The homogeneity of variances was evaluated by the Bartlett's test (SAS Institute, 2009). The degrees of freedom of the denominator were adjusted by the method Kenward and Roger because variances were not homogeneous (Moser, 2004). The factor Year of experiment (YOE) was considered as random in evaluating the response of treatments over time because, even though climatic variability exerts a major role in influencing the amount of RSN in the soil profile, it is not a controllable factor. The Block factor was also considered as a random effect. Mean comparisons were performed with the LSMEANS statement, using Tukey as adjustment method.

\section{Results}

The statistical analysis indicated that treatments, here intended as individual combinations of crop species and fertilisation applied, were highly significant in all the three years (Tables 3 and 4). In the second and third year (2011 and 2012) the Soil layers effect and the Treatments $\mathrm{x}$ layers interaction effect were also highly significant (Table 3). This implies an uneven distribution of RSN across soil layers, with differences depending on the treatment.

In the first year (2010) the RSN cumulated over the soil profile of the giant reed unfertilised Control was significantly lower, i.e. $13 \%$ of RSN of the wheat reference crop (Figure 1A). When cattle slurry was applied (CS20) the RSN of giant reed remained significantly lower than RSN of wheat. The effect of cattle slurry application on RSN was much more pronounced for poplar. While the RSN of poplar Control was $20 \%$ of RSN of wheat, RSN of CS20 was of the same level as RSN of wheat. In the second year (2011) the effect of fertilisation on RSN of giant reed and poplar was confirmed (Figure 1B). The RSN for the giant reed Control was only

Table 1. Main chemical and physical characteristics of the soil.

\begin{tabular}{|c|c|c|c|c|}
\hline Soil characteristics & $\begin{array}{c}\text { 0-0.2 m } \\
\text { Mean (SD) }\end{array}$ & $\begin{array}{c}\text { S } \\
0.2-0.4 \mathrm{~m} \\
\text { Mean (SD) }\end{array}$ & $\begin{array}{c}\text { 0.4-0.6 m } \\
\text { Mean (SD) }\end{array}$ & $\begin{array}{c}0.6-0.8 \mathrm{~m} \\
\text { Mean (SD) }\end{array}$ \\
\hline Sand $(2.0-0.05 \mathrm{~mm})\left(\mathrm{g} \mathrm{kg}^{-1}\right)$ & $367(34.5)$ & $343(79.9)$ & $332(24.8)$ & $360(51.9)$ \\
\hline Silt $(0.05-0.002 \mathrm{~mm})\left(\mathrm{g} \mathrm{kg}^{-1}\right)$ & $400(28.3)$ & $405(48.3)$ & $423(23.9)$ & $432(61.8)$ \\
\hline Clay $(<0.002 \mathrm{~mm})\left(\mathrm{g} \mathrm{kg}^{-1}\right)$ & $233(27.4)$ & $252(37.6)$ & $245(15.1)$ & $208(18.0)$ \\
\hline $\mathrm{pH}$ in water & $7.86(0.15)$ & $7.82(0.21)$ & $7.81(0.18)$ & $7.89(0.19)$ \\
\hline $\mathrm{CaCO}_{3}$ active $\left(\mathrm{g} \mathrm{kg}^{-1}\right)$ & $6.23(0.85)$ & $6.53(0.95)$ & $6.44(1.21)$ & $7.79(1.20)$ \\
\hline $\mathrm{CaCO}_{3}$ total $\left(\mathrm{g} \mathrm{kg}^{-1}\right)$ & $14.9(1.31)$ & $15.3(0.65)$ & $15.2(1.19)$ & $16.4(1.73)$ \\
\hline Walkley and Black SOC $\left(\mathrm{g} \mathrm{kg}^{-1}\right)$ & $10.6(0.14)$ & $9.90(0.40)$ & $9.70(0.60)$ & $6.90(0.50)$ \\
\hline Kjeldahl N $\left(\mathrm{g} \mathrm{kg}^{-1}\right)$ & $0.85(0.04)$ & $0.81(0.04)$ & $0.76(0.07)$ & $0.48(0.08)$ \\
\hline Olsen P (mg kg-1) & $18.6(10.3)$ & $12.9(2.53)$ & $13.1(7.04)$ & $5.85(1.28)$ \\
\hline Exchangeable K (mg kg-1) & $504(69.2)$ & $371(85.6)$ & $286(76.0)$ & $247(73.3)$ \\
\hline
\end{tabular}

Table 2. Monthly accumulated precipitation and average temperature at Anzola dell'Emilia (Bologna), Northern Italy.

\begin{tabular}{|c|c|c|c|c|c|c|c|c|c|c|c|c|c|}
\hline & Jan. & Feb. & Mar. & Apr. & May & Jun. & Jul. & Aug. & Sep. & Oct. & Nov. & Dec. & \\
\hline & \multicolumn{12}{|c|}{ Precipitation (mm) } & Total \\
\hline 2010 & 27.1 & 84.2 & 80.4 & 58.2 & 106.6 & 137.0 & 26.2 & 54.4 & 42.4 & 93.0 & 99.4 & 59.2 & 868 \\
\hline 2011 & 40.0 & 50.6 & 62.8 & 8.0 & 60.8 & 122.8 & 32.0 & 0.0 & 19.6 & 72.0 & 20.4 & 14.2 & 503 \\
\hline 2012 & 9.0 & 57.3 & 3.4 & 101.6 & 91.2 & 24.2 & 2.6 & 0.4 & 127.4 & 106.2 & 90.2 & 34.2 & 648 \\
\hline \multirow[t]{2}{*}{ 30-year average } & 55.2 & 48.0 & 70.2 & 68.7 & 63.2 & 58.4 & 45.1 & 58.2 & 65.2 & 78.2 & 80.4 & 64.2 & 755 \\
\hline & \multicolumn{12}{|c|}{ Temperature $\left({ }^{\circ} \mathrm{C}\right)$} & verages \\
\hline 2010 & 0.9 & 3.7 & 7.5 & 12.9 & 17.5 & 21.9 & 25.2 & 22.8 & 18.1 & 12.2 & 9.3 & 1.3 & 12.8 \\
\hline 2011 & 2.1 & 4.4 & 8.4 & 14.1 & 18.6 & 22.0 & 23.5 & 26.1 & 22.5 & 13.2 & 7.3 & 3.2 & 13.9 \\
\hline 2012 & 1.8 & 0.3 & 11.6 & 13.2 & 18.1 & 24.5 & 27.0 & 27.7 & 20.3 & 15.2 & 10.5 & 2.1 & 14.4 \\
\hline 30-year average & 1.5 & 4.1 & 8.1 & 12.4 & 16.9 & 20.8 & 23.5 & 23.2 & 19.6 & 14.1 & 7.5 & 2.8 & 12.9 \\
\hline
\end{tabular}


$22 \%$ compared to wheat, with no significant differences between Control and CS20. For poplar, RSN was 35\% and $80 \%$ respectively for Control and CS20, compared to wheat. The response of sorghum was similar to poplar: the RSN was $32 \%$ and $68 \%$, respectively, for Control and CS20, compared to wheat. It must be noted, however, that the RSN for poplar CS20 was not significantly different from wheat, while CS20 for sorghum remained significantly lower than RSN for wheat.

In the third year (2012) the ability of giant reed in reducing RSN was further substantiated (Figure 1C). The RSN for giant reed was $20 \%$ and $22 \%$ respectively, for Control and CS20, compared to wheat. In contrast, the RSN for poplar was only $16 \%$ with Control, but raised impressively to $+57 \%$ with respect to wheat. This was the only case in three years in which RSN for poplar CS20 was significantly higher than the reference crop of wheat. The response to cattle slurry application in sorghum was in intermediate position between giant reed and poplar. The RSN for sorghum was $35 \%$ and $56 \%$ respectively for Control and CS20, compared to wheat. These RSN values for sorghum, however, were significantly lower than RSN of wheat.

The highly significant interaction between treatments and soil layers observed for the years 2011 and 2012 implies an uneven distribution of RSN across soil layers.
Table 3. Effect of treatments and soil layers on the residual soil nitrate in the three years of experiment. Treatments are individual combinations of the crop species $\times$ fertilisation applied. In 2010: Arundo Control, Arundo CS20, poplar Control, poplar CS20, wheat; In 2011 and 2012: Arundo Control, Arundo CS20, poplar Control, poplar CS20, sorghum Control, sorghum CS20, wheat.

\begin{tabular}{lcccc} 
& \multicolumn{4}{c}{ Year 2010 } \\
Effects & Num DF & Den DF & F value & Pr $>$ F \\
Treatments & 4 & 19 & 20.27 & $<0.0001$ \\
Soil layers & 3 & 19 & 1.04 & 0.3964 \\
\hline Treatments*layers & 12 & 19 & 1.76 & 0.1319 \\
Effects & Num DF & Den DF & F value & Pr $>$ F \\
Treatments & 6 & 54 & 31.47 & $<0.0001$ \\
Soil layers & 3 & 54 & 44.97 & $<0.0001$ \\
\hline Treatments*layers & 18 & 54 & 4.50 & $<0.0001$ \\
& & Year 2012 & \\
Effects & Num DF & Den DF & F value & Pr $>$ F \\
Treatments & 6 & 54 & 51.61 & $<0.0001$ \\
Soil layers & 3 & 54 & 2.76 & 0.0511 \\
\hline Treatments*layers & 18 & 54 & 2.35 & 0.0081 \\
\hline
\end{tabular}
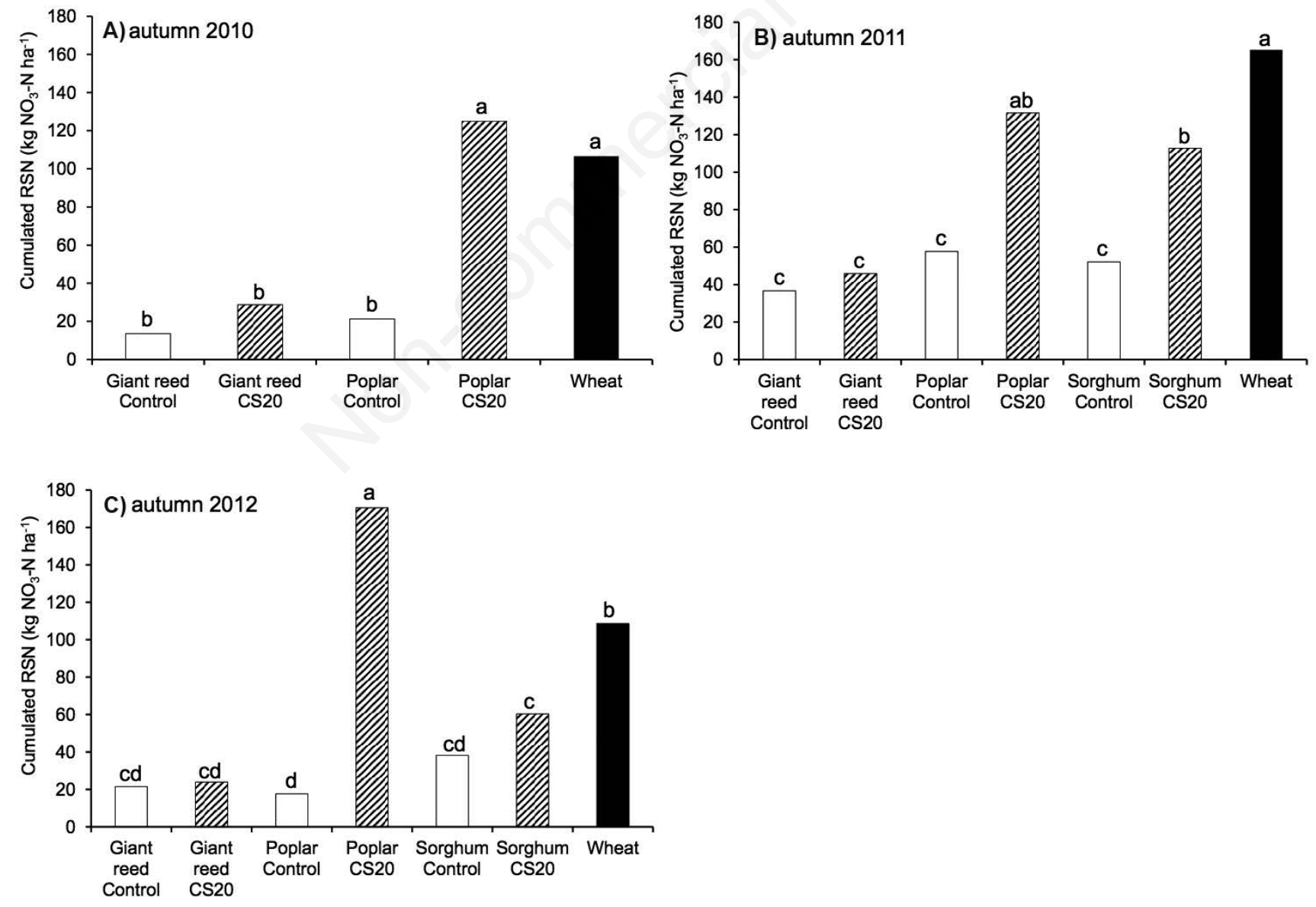

Figure 1. Cumulated residual soil nitrate (RSN) for the depth 0.0-0.8 m, in the autumn of the years 2010 (A), 2011 (B), and 2012 (C). Sampling dates were: 30 November 2010, 6 December 2011 and 5 December 2012. 
In the first year (2010) the RSN was evenly distributed across soil layers for treatments giant reed Control, poplar Control and giant reed CS20 with low RSN (Table 4). In contrast, for wheat the RSN was not only higher but also tended to increase with soil depth. In case of poplar CS20 the RSN raised until the layer 0.2$0.4 \mathrm{~m}$ and subsequently tended to decrease with depth.

In the following year (2011) the RSN was generally more abundant compared to the precedent year. In contrast with the previous year most of RSN for all treatments was present in the upper layers $0-0.2 \mathrm{~m}$ and 0.2-0.4 $\mathrm{m}$ and decreased with depth.

In the third year (2012) the pattern of RSN distribution was quite similar to the one observed in the first year 2010. The RSN was almost evenly distributed across layers for giant reed Control, poplar Control, and giant reed CS20. In contrast, for the treatments poplar CS20, sorghum Control and sorghum CS20 there was a higher RSN in the layer 0.2-0.4 m compared to the upper layer 0$0.2 \mathrm{~m}$. For wheat the RSN increased progressively until 0.4-0.6 m and then remained stable for the layer $0.6-0.8 \mathrm{~m}$.

\section{Discussion}

Overall, the outcomes for cumulated RSN of the three years can be summarised as follows:

i) as far as the unfertilised Control is regarded, there were no significant differences between the RSN values observed for giant reed and the ones for poplar and sweet sorghum in the three years of experiment. Importantly, RSN for the three energy crops with unfertilised Control was always significantly lower than the RSN of the reference crop of wheat in the three years of the experiment. The practical implication is that all the three dedicated energy crops, if not fertilised with $\mathrm{N}$, are well suited for reducing RSN;

ii) the treatment giant reed CS20 never determined RSN significantly higher than that in giant reed Control, in the three years; The RSN for giant reed with treatment CS20 was significantly lower than the reference crop of wheat in all the three years. This implies that giant reed is particularly well suited to reduce RSN even in situations of high N supply;

iii) in contrast, for poplar the treatment CS20 determined a significant RSN increase with respect to Control in all the three years. Nevertheless, the RSN observed for poplar CS20 was significantly higher than the reference crop of wheat in one out of 3 years. Therefore, poplar is certainly less suited than giant reed in reducing RSN when cattle slurry is applied;

iv) results of sweet sorghum are in an intermediate position: the treatment CS20 had a significantly higher RSN with respect to Control in the year 2011 but not in 2012. However, the RSN values for sorghum were significantly lower with respect to the reference crop of wheat in both 2011 and 2012. Hence, also sweet sorghum can be regarded as poorly suited to reduce RSN if cattle slurry is applied.

The patterns of RSN distribution across the soil layers in the three years of repeated cattle slurry supply substantiate the hypothesis that giant reed was much more effective in removing RSN than poplar and sorghum. In the three years of experiments the RSN for both giant reed Control and giant reed CS20 were evenly distributed across soil layers. Interestingly, these patterns of RSN across soil layers are quite similar to the ones of water uptake reported for giant reed by Barco et al. (2018). This suggests that giant reed possesses a uniform, well distributed rooting system

Table 4. Amounts of residual soil nitrate $\left(\mathrm{kg} \mathrm{NO}_{3}-\mathrm{N} \mathrm{ha}^{-1}\right)$ in the individual soil layers of the $0-0.8 \mathrm{~m}$ soil profile, for the crop and fertilisation treatments, in the autumn of the years 2010, 2011, and 2012. Lowercase letters indicate differences within columns, i.e. between soil layers within treatments. Means sharing common letters are not significantly different for $\mathrm{P}<0.05$, Tukey test.

\begin{tabular}{|c|c|c|c|c|c|c|c|}
\hline \multicolumn{7}{|c|}{ Date of sampling 30 November 2010} & Wheat \\
\hline $0-0.20$ & $4.6^{\mathrm{a}}$ & $10.1^{\mathrm{a}}$ & $6.3^{\mathrm{a}}$ & $21.4^{\mathrm{b}}$ & & & $12.0^{\mathrm{b}}$ \\
\hline $0.20-0.40$ & $4.4^{\mathrm{a}}$ & $5.8^{\mathrm{a}}$ & $6.4^{\mathrm{a}}$ & $43.2^{\mathrm{a}}$ & & & $21.8^{b}$ \\
\hline $0.40-0.60$ & $3.2^{\mathrm{a}}$ & $5.6^{\mathrm{a}}$ & $6.1^{\mathrm{a}}$ & $32.3^{\mathrm{ab}}$ & & & $28.9^{a b}$ \\
\hline $0.60-0.80$ & $1.4^{\mathrm{a}}$ & $7.3^{\mathrm{a}}$ & $2.5^{\mathrm{a}}$ & $28.0^{\mathrm{ab}}$ & & & $48.9^{\mathrm{a}}$ \\
\hline Layers & \multicolumn{2}{|c|}{ Giant reed } & $\begin{array}{l}\text { f samplit } \\
\text { Control }\end{array}$ & $\begin{array}{l}\text { ecemb } \\
\text { cs20 }\end{array}$ & Control & CS20 & Wheat \\
\hline $0-0.20$ & $10.3^{\mathrm{a}}$ & $20.3^{\mathrm{a}}$ & $23.8 \mathrm{a}$ & $51.3^{\mathrm{a}}$ & $19.5^{\mathrm{a}}$ & $49.8^{\mathrm{a}}$ & $64.8^{\mathrm{a}}$ \\
\hline $0.20-0.40$ & $11.5^{\mathrm{a}}$ & $13.8^{\mathrm{ab}}$ & $18.5^{\mathrm{a}}$ & $29.0^{\mathrm{b}}$ & $14.5^{\mathrm{ab}}$ & $33.3^{b}$ & $63.8^{\mathrm{a}}$ \\
\hline $0.40-0.60$ & $8.3^{\mathrm{a}}$ & $7.0^{\mathrm{b}}$ & $11.5^{\mathrm{ab}}$ & $36.3^{b}$ & $12.3^{\mathrm{ab}}$ & $21.0^{\mathrm{bc}}$ & $24.5^{b}$ \\
\hline $0.60-0.80$ & $6.7^{\mathrm{a}}$ & $4.8^{b}$ & $3.9^{\mathrm{b}}$ & $15.0^{c}$ & $5.8^{\mathrm{b}}$ & $8.5^{\mathrm{c}}$ & $12.0^{\mathrm{b}}$ \\
\hline Layers & Git & CS20 & $\begin{array}{l}\text { of sampli } \\
\text { Control }\end{array}$ & $\begin{array}{l}\text { ecemb } \\
\text { cs20 }\end{array}$ & Control & CS20 & Wheat \\
\hline $0-0.20$ & $8.0^{\mathrm{a}}$ & $9.4^{\mathrm{a}}$ & $9.0^{\mathrm{a}}$ & $31.6^{c}$ & $7.4^{\mathrm{a}}$ & $10.2^{\mathrm{a}}$ & $14.2^{c}$ \\
\hline $0.20-0.40$ & $6.2^{\mathrm{a}}$ & $7.8^{\mathrm{a}}$ & $4.3^{\mathrm{a}}$ & $56.9^{\mathrm{a}}$ & $12.3^{\mathrm{a}}$ & $18.7^{\mathrm{a}}$ & $24.5^{b c}$ \\
\hline $0.40-0.60$ & $6.0^{\mathrm{a}}$ & $5.4^{\mathrm{a}}$ & $3.2^{\mathrm{a}}$ & $38.2^{\mathrm{bc}}$ & $10.3^{\mathrm{a}}$ & $17.2^{\mathrm{a}}$ & $35.8^{\mathrm{a}}$ \\
\hline $0.60-0.80$ & $1.3^{\mathrm{a}}$ & $1.2^{\mathrm{a}}$ & $1.1^{\mathrm{a}}$ & $43.8^{b}$ & $8.2^{\mathrm{a}}$ & $14.2^{\mathrm{a}}$ & $34.2^{\mathrm{ab}}$ \\
\hline
\end{tabular}


activity until $0.8 \mathrm{~m}$ soil depth. It is likely that the patterns of RSN distribution across soil profile for poplar, sorghum and wheat were strongly influenced by the year-to-year variability of weather conditions. In particular, whilst in the autumn 2011 the RSN tended to be more abundant in the upper soil layers (0-0.2 $\mathrm{m}$ and $0.2-0.4 \mathrm{~m})$, in the preceding year 2010 and in the subsequent 2012 it is plausible that some migration of RSN across soil layers had already occurred at time of sampling. It can be hypothesised that nitrate movement was facilitated by the abundance of RSN in the soil layers. This can be noticed in particular for wheat and poplar CS20 in autumn 2010, and for wheat, poplar CS20, sorghum Control and sorghum CS20 in autumn 2012. This hypothesis is corroborated by the amount of precipitation occurred during the period from August to November in the three years: $289 \mathrm{~mm}$ in 2010, $112 \mathrm{~mm}$ in 2011 and $324 \mathrm{~mm}$ in 2012. It is worth noting that precipitation in the period August-November 2011 was merely $40 \%$ of the $30-$ year average, whilst for the other two years precipitations were very close to the long-term average $(+3 \%$ for 2010 and $+15 \%$ 2012). Hence, RSN situations similar to the ones observed in the first and the third year are presumably more frequent under our environmental conditions.

Ceotto (1999), working on a silty-clay soil of the Po Valley, reported RSN content integrated over the $0-1.2 \mathrm{~m}$ soil profile at harvest time of several crops, notably winter wheat, sugarbeet (Beta vulgaris L.), soybean (Glicine max Merr.), maize and grain sorghum, treated with three levels of fertilisation in the years 1994, 1995 and 1996. For both wheat and sugar beet an amount of RSN of 40-60 $\mathrm{kg} \mathrm{NO}_{3}-\mathrm{N} \mathrm{ha}^{-1}$ was present at harvest time, while in the subsequent November the RSN raised to $100-120 \mathrm{~kg} \mathrm{NO}_{3}-\mathrm{N} \mathrm{ha}^{-1}$. In case of soybean and grain sorghum the amount of RSN was merely 40-60 $\mathrm{kg} \mathrm{NO}_{3}-\mathrm{N} \mathrm{ha}^{-1}$. The author pointed out that: i) a conspicuous fraction of RSN present in autumn accumulated during the period in which the soil remained bare; ii) such amount was poorly influenced by the three levels of fertilisation applied to the crops. Our data on winter wheat are very close to the ones reported by the previous study.

Our observations on the unfertilised energy crops are also consistent with the hypothesis that a soil cover with a green canopy extended over a long growing season is an effective measure to diminish the amount of RSN in the autumn. However, beside to the active green foliage the desirable crop traits for removing RSN are a deep and well distributed rooting system and an extended $\mathrm{N}$ uptake throughout the growing season.

Nevertheless, our data clearly indicated that the supply of 20 $\mathrm{mm}$ cattle slurry substantially raised the amount of RSN, notwithstanding the extended canopy cover exerted by both poplar SRC and sweet sorghum. Our explanation is that the $\mathrm{N}$ applied with cattle slurry overtook the $\mathrm{N}$ uptake capability of both species. Our findings are partially in contrast with the outcomes of the previous study of Ceotto (2009) who reported limited influence of fertilisation level, and overwhelming influence of soil cover on RSN.

Giant reed was the only crop able to assure low levels of RSN despite the relatively large amount of applied cattle slurry. Such ability of giant reed is similar to the one reported by Ceotto and Spallacci (2006) for alfalfa (Medicago sativa L.) that received pig slurry application in a silty-clay soil of the same experimental site. This study indicated that at the end of the growing seasons 1994 and 1995 the amount of RSN ranged from 16 to $29 \mathrm{~kg} \mathrm{NO}_{3}-\mathrm{N} \mathrm{ha}^{-1}$ in the soil layer 0.-0.4 $\mathrm{m}$ irrespective of the amount of slurry applied. In fact, Raun et al. (1999) highlighted that the soil-alfalfa system has a buffering capacity that is able to compensate for the surplus $\mathrm{N}$ applied. Our study clearly indicates that the soil-giant reed system exerts an equivalent effect. Our findings on RSN for giant reed are consistent with those of Ceotto et al. (2015) who reported productivity and $\mathrm{N}$-use efficiency for the same giant reed experiment. The application of CS20 significantly increased yield compared to Control in five consecutive years, from 2008 to 2012. The agronomic efficiency of applied $\mathrm{N}\left(\mathrm{AE}_{\mathrm{N}}\right)$ varied from 18 to $51 \mathrm{~kg}$ dry matter $\mathrm{kg} \mathrm{N}$ applied $^{-1}$ and the recovery efficiency of applied $\mathrm{N}$ $\left(\mathrm{RE}_{\mathrm{N}}\right)$ varied from 0.119 to $0.385 \mathrm{~kg} \mathrm{~N}$ uptake $\mathrm{kg} \mathrm{N}$ applied ${ }^{-1}$. In this study we add that giant reed not only takes up soil $\mathrm{N}$ in the absence of fertilisation but also it responds generously to cattle slurry applications without detrimental effect on RSN. It is worth noting that the years 2010, 2011 and 2012 were respectively the third, the fourth, and the fifth years of consecutive cattle slurry applications to the same plots, and we found no evidence of $\mathrm{N}$ saturation of the giant reed cropping system. This was due to the favourable environmental conditions for giant reed growth encountered in this experiment. Our explanation is that, beside the $\mathrm{N}$ removed annually with aboveground biomass, the belowground standing biomass, notably the rhizomes, allow additional storage for $\mathrm{N}$ uptake by the crop. On the contrary, it is plausible that poplar become $\mathrm{N}$ saturated after five years of repeated cattle slurry application: in fact, high amount of RSN in 2012 corroborates this hypothesis. Our observations on RSN for sweet sorghum are also in good agreement with Ceotto et al. (2014) who reported on biomass yield and $\mathrm{N}$-use efficiency for the same sweet sorghum experiment. Owing to the high $\mathrm{N}$ uptake achieved by the crop without fertilisation, combined with the modest $\mathrm{RE}_{\mathrm{N}}$, these authors concluded that sweet sorghum should be regarded as poorly suited to receive cattle slurry application. In this study we add the insight that cattle slurry application on sorghum leaves higher amounts of $\mathrm{RSN}$ and therefore increases the risk of nitrate leaching. This is consistent with Chen et al. (2017) who reported high levels of nitrate accumulation during the crop-growing period in fertilised plots cropped to energy sorghum on marginal land in China.

Moreover, our findings on poplar are also consistent with those of Ceotto et al. (2016) who indicated that poplar SRC is not a firstchoice crop for cattle slurry fertilisation, for three reasons: i) $\mathrm{N}$ supply determined poor $\mathrm{AE}_{\mathrm{N}}$; ii) a modest fraction of applied $\mathrm{N}$ was recovered with the harvested biomass (i.e. low $\mathrm{RE}_{\mathrm{N}}$ ); iii) the rise of $\mathrm{N}$ concentration in aboveground biomass is detrimental for the quality of the feedstock product for combustion. In fact, Kauter et al. (2003) indicated that $0.6 \% \mathrm{~N}$ is the upper allowable threshold in feedstock biomass for combustion. In this study we disclose an additional important reason to avoid cattle slurry fertilisation to poplar SRC: the RSN was substantially high in the autumn, and therefore poses environmental concern of nitrate leaching.

\section{Conclusions}

Our findings suggest simple and straightforward conclusions: i) if $\mathrm{N}$ fertilisation is not applied, the three dedicated energy crops giant reed, sweet sorghum and poplar provide in similar manner the environmental benefit of leaving low amounts of RSN in the autumn; ii) the real advantage of giant reed cultivation becomes evident only when cattle slurry is applied. Unlike poplar and sorghum, Giant reed exerts effective soil nitrate removal even with relatively high rate of cattle slurry application. Consequently, it leaves low amounts of RSN prone to leaching, in autumn. Hence, this species can be regarded as particularly well suited not only to utilise livestock effluents, but also to reduce the risk of nitrate pollution in many land use situations.

The environmental benefit of soil nitrate removal should be 
regarded as supplementary to the substantial carbon sequestration in both soil and belowground standing biomass, promoted by both giant reed and poplar SRC.

\section{References}

Addiscott TM, 2005. Nitrate, agriculture and the environment. CABI Publishing, Wallingford, UK.

Barbosa B, Boléo S, Sidella S, Costa J, Duarte MP, Mendes B, Cosentino SL, Fernando AL, 2015. Phytoremediation of heavy metal-contaminated soils using the perennial energy crops Miscanthus spp. and Arundo donax L. Bioenerg. Res. 8:1500-11.

Barco A, Maucieri C, Borin M, 2018. Root system characterization and water requirements of ten perennial herbaceous species for biomass production managed with high nitrogen and water inputs. Agric. Water Manage. 196:37-47.

Bausch WC, Delgado JA, 2005. Impact of residual soil nitrate on in-season nitrogen applications to irrigated corn based on remotely sensed assessments of crop nitrogen status. Precis. Agric. 6:509.

Blake GR, Hartge KH, 1986. Bulk density. In: Klute A. (Ed.), Methods of soil analysis. Part 1. Physical and mineralogical methods. Agronomy monograph no. 9 ( $2^{\text {nd }}$ ed.). ASA, SSSA, CSA, Madison, WI, USA.

Ceotto E, 1999. Exploring cropping systems of the low Po Valley using the system approach. MSc thesis, Wageningen Agricultural University, Wageningen, The Netherlands. Available from: http://edepot.wur.nl/180490 Accessed: 28 January 2018.

Ceotto E, Castelli F, Moschella A, Diozzi M, Di Candilo M, 2014. It is not worthwhile to fertilize sweet sorghum (Sorghum bicolor L. Moench) with cattle slurry. Productivity and nitrogen-use efficiency. Ind. Crop. Prod. 62:380-6.

Ceotto E, Castelli F, Moschella A, Diozzi M, Di Candilo M, 2015. Cattle slurry fertilization to giant reed (Arundo donax L.): biomass yield and nitrogen use efficiency. Bioenerg. Res. $8: 1252-62$.

Ceotto E, Castelli F, Moschella A, Diozzi M, Di Candilo M, 2016. Poplar short rotation coppice is not a first choice crop for cattle slurry fertilization: biomass yield and nitrogen-use efficiency. Ind. Crop. Prod. 85:167-73.

Ceotto E, Spallacci P, 2006. Pig slurry applications on alfalfa: productivity, solar radiation utilization, $\mathrm{N}$ and $\mathrm{P}$ removal. Field Crops Res. 95:135-55.

Chen F, Ameen A, Tang CC, Du F, Yang XL, Xie GH, 2017. Effects of nitrogen fertilization on soil nitrogen for energy sorghum on marginal land in china. Agron. J. 109:1-10.

Council Directive 91/676/EEC of 12 December 1991 concerning the protection of waters against pollution caused by nitrates from agricultural sources. Available from: http://eurlex.europa.eu/legal-content/en/ALL/?uri=CELEX:31991L 0676. Accessed: 31 January 2018.

Cosentino SL, Patanè C, Sanzone E, Testa G, Scordia D, 2016. Leaf gas exchange, water status and radiation use efficiency of giant reed (Arundo donax L.) in a changing soil nitrogen fertilization and soil water availability in a semi-arid Mediterranean area. Eur. J. Agron. 72:56-69.

Follett RF, 2001. Nitrogen transformation and transport process. In: Follett RF, Hatfield JL (Eds.), Nitrogen in the environment: sources, problems and management. Elsevier Science, Amsterdam, The Netherlands, pp 17-44.

Kauter D, Lewandowski I, Claupein W, 2003. Quantity and quality of harvestable biomass from Populus short rotation coppice for solid fuel use - a review of the physiological basis and management influences. Biomass Bioener. 24:411-27.

Keeney DR, Hatfield JL, 2001. The nitrogen cycle, hystorical perspectives, and current and potential future concerns. In: Follett RF, Hatfield JL (Eds.), Nitrogen in the environment: sources, problems and management. Elsevier Science, Amsterdam, The Netherlands, pp 3-16.

Keeney DR, Nelson DW, 1982. Nitrogen-inorganic forms. In: Page AL (Ed.), Methods of Soil Analysis, Part 2, $2^{\text {nd }}$ ed. Agron. Monogr. 9, 643-698, ASA and SSSA, Madison, WI, USA.

Liu Z, Chen Z, Ma P, Meng Y, Zhou J, 2017. Effects of tillage, mulching and $\mathrm{N}$ management on yield, water productivity, $\mathrm{N}$ uptake and residual soil nitrate in a long-term wheat-summer maize cropping system. Field Crops Res. 213:154-64.

Littell RC, Milliken GA, Stroup WW, Wolfinger RD, 1996. SAS system for mixed models. SAS Institute Inc., Cary, NC, USA.

Moser EB, 2004. Repeated measures modeling with PROC MIXED. 29th annual SAS Users Group International Conference. Montreal, Canada. Available from: http://www2. sas.com/proceedings/sugi29/188-29.pdf

Nocentini A, Monti A, 2017. Land-use change from poplar to switchgrass and giant reed increases soil organic carbon. Agron. Sustain. Dev. 37:23.

Olson RA, Frank KD, Deibert EJ, Dreier AF, Sander DH, Johnson VA, 1976. Impact of residual mineral $\mathrm{N}$ in soil on grain protein yields of winter wheat and corn. Agron J. 68:769-72.

Page AL, Miller RH, Keeney DR, 1982. Methods of soil analysis. Part 2. 2nd ed. Agron. Monogr. 9. ASA and SSSA, Madison, WI, USA.

Raun WR, Johnson GV, Phillips SB, Thomason WE, Dennis JL, Cossey DA, 1999. Alfalfa yield response to nitrogen applied after each cutting. Soil Sci. Soc. Am. J. 63:1237-43.

SAS Institute 2009. SAS/STAT 9.2 User's Guide, 2nd edn. Cary, NC, USA.

Soil Survey Staff, 2003. Keys to Soil Taxonomy, ninth ed. USDANatural Resources Conservation Service, Washington, DC, USA.

Stockdale EA, Gaunt JL, Vos J, 1997. Soil-plant nitrogen dynamics: what concepts are required? Eur. J. Agron. 7:145-59.

Webster RJ, Driever SM, Kromdijk J, McGrath J, Leakey ADB, Siebke K, Demetriades-Shah T, Bonnage S, Peloe T, Lawson T, Long SP, 2016. High C3 photosynthetic capacity and high intrinsic water use efficiency underlies the high productivity of the bioenergy grass Arundo donax. Sci Rep. 6:20694. 